\title{
Eru íslenskir neytendur smálána ólæsir á fjármál?
}

\author{
Davíð Arnarson, Kári Kristinsson og Sigurður Guðjónsson ${ }^{1}$
}

\begin{abstract}
Ágrip
Mikil umræða hefur skapast á Íslandi um hin svo kölluðu smálánafyrirtæki. Annars vegar finnst mörgum að smálán bæti við flóru fjármálavara sem eru í boði fyrir neytendur. Hins vegar er hægt að líta svo á að smálán séu ekki annað en okurlánastarfssemi, enda vextir á pessum lánum afar háir. Prátt fyrir að pólitísk umræða um smálán hafi verið nokkur hafa pau hins vegar verið nánast óskoðuð í fræðasamfélaginu. Î pessari grein skoðum við hvort neytendur smálána séu með verra fjármálalæsi en hinn almenni neytandi. Niðurstöðurnar gefa til kynna að neytendur smálána séu með verra fjármálalæsi en almennir neytendur. Peir eru einnig yngri, líklegri til að vera karlkyns, með lægri tekjur og menntun.
\end{abstract}

\section{Abstract}

Considerable discussion has taken place in Iceland regarding firms offering small loans such as payday loans or microfinance loans. On one side people view these loans as adding to the choice of financial products available to consumers, while on the other side these loans are often viewed as loansharking as the annual interest rate is high. However, very little of this discussion has taken place in the Icelandic academic community and as a result no research has been conducted on this market. In this paper we investigate whether consumers of these small loans are less financially literate than the general population. We find that these consumers are less financially literate than the general population. They are also younger, more likely to be male, with less income and lower education.

JEL flokkun: M1; M14.

Lykilorð: Smálán; fjármálalæsi; neytendahegðun; örlán.

Keywords: Payday loan; financial illiteracy; consumer behaviour; microfinance loans.

\section{Are Icelandic consumers of payday loans financially illiterate?}

1 Davíð Arnarsson er sjálfstætt starfandi ráðgjafi. Netfang: david@crv.is. Kári Kristinsson er dósent við Háskóla Íslands. Netfang: karik@hi.is. Sigurður Guðjónsson er lektor við Háskólann á Akureyri. Netfang: sigurdurg@unak.is

This work is licensed under a Creative Commons Attribution 4.0 License.

DOI: https://doi.org/10.24122/tve.a.2018.15.2.4

(C) Tímarit um viðskipti og efnahagsmál

www.efnahagsmal.is 


\section{Inngangur}

Til pess að̃ geta lágmarkað áhrif ytri pátta á fjárhagslega velgengni og geta tekið upplýstar ákvarðanir tengdar fjármálum parf neytandi að búa að góðu fjármálalæsi (Breki Karlsson, 2010). Porri neytenda parf á einhverjum tímapunkti í sínu lífi að taka ákvörðun tengda fjárfestingu og sparnaði. Prátt fyrir pað hafa rannsóknir sýnt að neytendur búa almennt yfir takmörkuðum skilningi á fjármálapjónustu sem í boði er (OECD, 2005). Margar ástæður eru taldar liggja að baki og tekur skýrsla Efnahags- og framfarastofnunarinnar (OECD) nokkrar peirra fyrir, p.á.m. áhrif aukins upplýsingaflæðis í formi aukinnar markaðssetningar sem og fjölgun peirra kosta sem neytendum bjóðast. Neytendur eru taldir eiga erfitt með að átta sig á kostnaði sem fylgir pví að fá lánaða peninga, peim reynist erfitt að gera greinarmun á tilboðum fjármálastofnana og með tilkomu netsins og viðskipta í gegnum pað geta neytendur átt erfiðara um vik að gera greinarmun á óprúttnum aðilum og peim sem stunda venjubundin viðskipti (OECD, 2005; Viðskiptaráðuneytið, 2009). Fyrir vikið hefur umræða um lagasetningu til verndar neytendum á fjármálamarkaði sprottið upp bæði hér á Íslandi sem og erlendis.

Í pessari grein skoðum við hvort neytendur smálána séu með verra fjármálalæsi en hinn almenni neytandi. Við byrjum á pví að skoða fjármálalæsi, bæði almennt og í tengslum við smálán sérstaklega. Pá verður komið inná hvernig rannsóknin var framkvæmd, niðurstöður kynntar og greinin endar á umræðu.

\section{Fjármálalæsi}

Rannsóknir á neytendum í Bandaríkjunum hafa sýnt að pví lakari, sem pekking neytenda er á sviði fjármála, peim mun lakari eru vaxtakjör peirra á t.d. kreditkortum og húsnæðislánum (Lusardi og Tufano, 2009). Рað borgar sig pví að búa að góðri pekkingu á sviði fjármála og pví fyrr sem neytandinn aflar sér peirrar pekkingar, peim mun betur settur er hann (Huston, 2012; Garg og Singh, 2018). Í rannsóknum um heim allan hafa komið fram vissir pættir sem spá fyrir um fjármálalæsi einstaklinga, p.á.m. hefur jákvæð fylgni greinst milli menntunar og fjármálalæsis, aldur og tekjur neytenda hafa einnig áhrif og mælast konur með marktækt lakara fjármálalæsi í nær öllum löndum sem tekin voru fyrir í rannsókn sem Atkinson og Messy (2012) unnu fyrir OECD. Rannsóknir hafa einnig sýnt fram á neikvætt samband milli fjármálalæsis og fjárhagslegar velgengni, t.d. lélegara ákvörðunartöku í lífeyrirssparnaði og yfirskuldsetningu (Gathergood, 2011; van Rooij, Lusardi og Alessie, 2011a; van Rooij, Lusardi, og Alessie, 2011b). Pó eru ekki allar rannsóknir einróma pegar kemur að tengslum fjármálalæsis og fjárhagslegar velgengni (Braunstein og Welch, 2002).

Engin altæk skilgreining er til fyrir fjármálalæsi (Huston, 2010) en við notum skilgreiningu OECD par er fjármálalæsi er skilgreint sem pekking og skilningur á fjármálatengdum atriðum, áhættu, ásamt getu og áræðni til pess að beita pessari pekkingu, sem og getu til pess að taka árangursríkar ákvarðanir á ýmsum sviðum fjármála (OECD, 2015).

\subsection{Fjármálalæsi neytenda}

Prátt fyrir að hugtakið fjármálalæsi hafi fyrst verið rannsakað af Bakken árið 1967 pá kom ekki fram almennileg skilgreining á hugtakin fyrr en árið 1992 og hafa fræðimenn verið iðnir við að skilgreina hugtakið á misjafnan hátt og par af leiðandi mælt pað á mjög misjafna vegu (Huston, 2010). Sandra J. Huston prófesor við tækniháskólann í Texas tók saman 52 gagnasett úr 72 rannsóknum á fjármálalæsi síðasta áratugar. Tilgangur rannsóknarinnar var að setja fram skýra skilgreiningu á hvað fjármálalæsi væri og hvað pað væri ekki, greina meginágalla mælitækja, útlista úrbætur og koma upp stöðluðum og viðurkendum mælitækjum til að mæla fjármálalæsi einstaklinga. Einnig tók hún saman fyrri skilgreiningar og túlkanir á hugtakinu. Meginniðurstöður Huston voru pær að $72 \%$ peirra 72 rannsókna sem voru athugaðar innihéldu ekki skilgreiningu á hugtakinu fjármálalæsi 
og 47\% peirra töldu fjármálalæsi aðeins vera pekkingu. Sammræmi milli mælitækja var mjög ábótavant og skortur var á útskýringum á mælingum sem gerði pað fræðimönnum erfitt um vik að bera saman verk sín og gagnasöfn. Samræmda hugmyndafræði vantaði milli rannsókna og oft mældu mælitækin, sem meta áttu fjármálalæsi, ekki nema hluta peirra atriða sem æskilegt væri svo raunverulegar niðurstöður fengjust. Huston taldi að lágmark 12 kjarnaspurningar pyrfti svo mæla mætti fjármálalæsi einstaklinga á fullnægjandi hátt (Huston, 2012). Prátt fyrir mismunandi skilgreiningar á fjármálalæsi pá nýtist skigreining OECD frá 2015 ágætlega eða sem pekking og skilningur á fjármálatengdum atriðum, áhættu, ásamt getu og áræðni til pess að beita pessari pekkingu og getu til pess að taka árangursríkar ákvarðanir á ýmsum sviðum fjármála. Gott fjármálalæsi á einnig að skila sér í betri fjárhagsstöðu, bæði fyrir einstaklinginn og samfélagið í heild (OECD, 2015).

Nýjasta viðamikla alpjólega rannsóknin á fjármálalæsi var framkvæmd af Atkinson og Messy (2012) fyrir OECD. Rannsóknin bar saman fjármálalæsi neytenda í 14 löndum. Tilgangur hennar var bæði að hanna alpjóðlegt mælitæki fyrir fjármálalæsi sem og að bera saman löndin sem tóku pátt. Athyglisverð útkoma rannsóknarinnar var ekki aðeins staðfesting fyrri rannsókna á tengslum lýðfræðilegra og félagslegra pátta við fjármálalæsi, heldur einnig tilurð viðurkennds mælitækis, sem hægt er að nota samtímis í mismunandi löndum. Mælitækin voru samræmd milli landa og voru spurningarnar alltaf á móðurmáli svarenda. Pó svo að spurningar væru samræmdar hljóðuð pær ekki alltaf eins heldur voru hannaðar til að kanna sömu pætti milli landa. Mældir voru og bornir saman prír pættir fjármálalæsis, p.e. pekking, viðhorf og hegðun, með 19 kjarnaspurningum í samræmi við viðmið um misjafnar víddir, sem sett voru fram í rannsókn Atkinson (2007) og lágmarksfjölda spurninga Huston (2010).

Flestar rannsóknir sem gerðar hafa verið á fjármálalæsi hafa verið gerðar í Bandaríkjunum. Par má helst nefna rannsóknir samtaka sem nefnd eru „Jumpstart“. Samtökin voru stofnuð í Bandaríkjunum 1995 og hafa alla tíð einbeitt sér að rannsóknum á fjármálalæsi framhaldskólanemenda (Jumpstart, 2005). Dr. Lewis Mandell hannaði spurningalistann fyrir prófið sem notað var annað hvert ár frá 1997 til 2006. Pví var ætlað að mæla breiða pekkingu á fjármálum. Niðurstöðurnar voru ekkert sérlega glæsilegar, en árið 1997 var meðalútkoman úr prófinu $57 \%$ sem er fall pví miðað var við $60 \%$ sem lágmarkseinkunn. Útkoman hefur aðeins versnað með árunum, en Mandell (2008) vann viðamikla rannsókn upp úr gögnunum par sem hann sýndi fram á sterk tengsl milli velgengni í prófinu og tekna, menntun foreldra og kynpætti svarenda.

Rannsóknir sem gerðar hafa verið utan Bandaríkjanna á fjármálalæsi og tengdum páttum hafa gefið svipaðar niðurstöður. Í Bretlandi hafa nokkrar rannsóknir verið unnar fyrir breska ríkið og meðal annars kannaði David Miles (2004) íbúđarlánamarkaðinn parlendis. Helstu niðurstöður hans voru pær að margir lántekendur hefðu bæði lítinn skilning á misjafnri langtíma áhættu milli lána og ofmátu getu sína til pess að standa við afborganir til langs tíma. Atkinson o.fl. (2007) gerðu einnig stóra grunnrannsókn að beiðni breska ríkisins, en tilgangur hennar var að skilgreina viss viðmið sem hægt væri að styðjast við í lagasetningu og mótun stefnu í almennri neyslufræðslu og fjármálaráðgjöf. Tekin voru viðtöl við 5.328 einstaklinga í öllu Bretlandi, par með talið Skotlandi, Wales og Norður Írlandi, svo úrtakið skýrði sem best pýðið með von um að hægt væri að byggja áframhaldandi rannsóknir á peim viðmiðum sem lögð vorum fram í henni. Viðmiðin sem Atkinson o.fl lögðu fram voru að skipta mætti getu og pekkingu einstaklinga á sviði fjármála niður í fjóra hluta. Í fyrsta lagi daglega stjórnun fjármuna, í öđru lagi fjárhagslegar áætlanir og skipulagning, í priðja lagi val á fjárhagslega tengdum vörum og í síðasta lagi að vera vel upplýstur um fjárhagsleg málefni. Niðurstöður peirra voru að meta parf alla pessa pætti svo hægt sé að leggja raunverulegt mat á getu og pekkingu einstaklinga á sviði fjármála. Auk pess skilaði rannsóknin pví að mælitækin sem notuð voru væru góður grunnur til að byggja á fleiri rannsóknir í framtíðinni. 
Í Ástralíu var einnig gerð viðamikil rannsókn á fjármálalæsi fullorðinna og peim páttum sem gætu skýrt mun milli einstaklinga, til dæmis lýðfræðilegra og félagslegra pátta. Líkt og rannsókn Mandell (2008) sýndi rannsókn Worthington (2006) fram á að vissir pættir höfðu sterk tengsl við útkomu mælinga á fjármálalæsi. Peir félagslegu pættir sem höfðu jákvæð áhrif voru meðal annars meiri menntun, háar tekjur og rekstur eða stjórnun fyrirtækja. Atvinnuleysi eða engin atvinnupátttaka, að hafa atvinnu af búskap og að hafa ekki lokið 10. bekk höfðu neikvæð áhrif á útkomuna. Peir lýðfræðilegu pættir sem höfðu áhrif voru kyn, pað er, karlar voru að jafnaði með hærra fjármálalæsi og konur og sömuleiðis hafði aldur áhrif. Peir sem eldri voru, voru almennt fjármálalæsari en yngri svarendur. Rannsóknin sem var unnin úr gögnum Roy Research's gaf ástralska ríkinu góðar vísbendingar um hvaða hópum pað ætti að einbeita sér að ef pað hyggðist bæta fjármálalæsi almennt (Worthington, 2006).

Ísland fær falleinkunn í fjármálalæsi samkvæmt rannsóknum Breka Karlssonar en hann hefur gert nokkra rannsóknir á pessu sviði hérlendis. Haft var eftir honum í Morgunblaðinu 2009 að „Fjármálalæsi Íslendinga er dapurt og kannanir sýna að fleiri foreldrar uppfræða börn sín um kynlíf en fjármál.“ (Morgunblaðið, 2009). Afar fáar fræðilegar rannsóknir á smálánum hafa verið gerðar á Íslandi til pessa. Í rannsóknum Breka Karlssonar á fjármálæsi var spurt um noktun peirra en svörun var of lítil svo vinna mætti marktækar niðurstöður upp úr peim (Breki Karlsson, forstöðumaður Stofnunar um fjármálalæsi, munnleg heimild 17. október 2012). Höfundar pessarar greinar telja pví að töluvert nýnæmi sé að pessari rannsókn.

\subsection{Fjármálalæsi og smálán}

Smálán eru ekki ný af nálinni erlendis og ganga undir mismunandi heitum. Í t.d.Bretlandi og Bandaríkjunum eru pau kölluð útborgunardagslán (e. Payday loan) og er markhópurinn fólk sem á erfitt með að ná endum saman í lok mánaðar (Heimild, samantekt Spegillsins á RÚV). Bandarísku lánin eru hins vegar að mörgu leyti frábrugðin peim íslensku (Stegman, 2007). Í Finnlandi eru pessi lán markaðssett á svipaða hátt og á Íslandi með áherslu á að lifa í núinu og velta ekki fyrir sér peim kostnaði sem fylgir pví að taka lánin (Parhaat Pikavipit, 2012; PIPARTBWA, 2012). Hérlendis eru nokkur smálánafyritæki starfandi og heita nöfnum eins og 1909, Múli, Hraðpeningar, Kredia og Aktíva. Lánin eru yfirleitt veitt til skamms tíma (15-30 daga), upphæð peirra er frá $10.000 \mathrm{kr}$. og upp að $80.000 \mathrm{kr}$. og pau bera misjafna vexti sem geta, með ákveðinni talnaleikfimi, orðið vel yfir 600\% á ársgrundvelli (Hraðpeningar.ehf, 2018; Morgunblaðið, 2009).

Rannsóknir sem gerðar hafa verið í Bandaríkjunum eru af ýmsum toga. Lawrence og Elliehausen (2008) skoðuðu til dæmis hverjir taka útborgunardagslán. Niðurstöður peirra bentu til pess að meginmarkhópurinn par ílandi væri fólk í millitekjuhópi með USD 25.000 til USD 49.999 í árstekjur, tveir priðju hlutar hópsins væru yngri en 45 ára og par af væru $36.4 \%$ undir 35 ára aldri. Af peim sem svöruðu spurningu er varðaði ánægju með síðasta útborgunardagslán er peir tóku voru 72,5\% ánægðir með pað og aðeins 12,2\% voru óánægðir. Af peim sem voru óánægðir með síðasta lán voru 61,6\% annaðhvort ósáttir með vexti eða gjöld af lánunum. Almennt voru neytendur jákvæðir gagnvart pjónustu lánafyrirtækjanna. Peir voru ósammála pví að ríkið ætti að takmarka fjölda lána en sammála pví að ríkið beitti sér í lækkuðum gjöldum tengdum lánunum (Elliehausen og Lawrence, 2008).

Í rannsókn Stegman (2007) á markaði útborgunardagslána í Bandaríkjunum kom fram að sumir bankar notuðu sams konar markaðssetningu á yfirdráttarheimildum sínum og hluti smálánafyrirtækjanna notuðu á sinni pjónustu, pjóustu sem pau hafa verið harðlega gagnrýnd fyrir. I pessari markaðssetningu fólst að bjóða viðskiptavinum að leysa á skjótan hátt úr tímabundum fjárhagsvanda með yfirdrætti áður en að útborgunardegi kom. Stegman kannaði einnig samkeppnihæfni North Carolina State Employee's Credit Union hér eftir SECU. SECU býður sínum viðskiptavinum sérstaka tegund útborgunar- 
dagslána (e. Salary Advance Loan (SALO)) á mun lægri vöxtum en bjóðast á almennum markaði. SECU hóf að bjóða SALO árið 2001, sem er samblanda af sparnaði og láni, með pað að markmiði að aðstoða fólk í fjárhagsvanda við að koma undir sig fótunum. Árlegar afskriftir af SALO voru 0,27\% og skiluðu 7\% árlegri raunávöxtun á árunum 2001 til 2005. Niðurstaða Stegman var sú að rúm væri fyrir lánapjónustu á mun lægri vöxtum en í boði voru á útborgunardagslánum í Bandaríkjunum, og að skilyrði væru fyrir hendi á aðkomu nýrra aðila er byðu vexti mitt á milli vaxta SALO og yfirdráttarvaxta bankanna, eða um $16-28 \%$ (Stegman, 2007).

Fleiri hafa rannsakað samkeppni á markaði pessara lána í Bandaríkjunum enda eftirspurn eftir peim mikil. Að minnsta kosti tíu milljón heimili tóku pessi lán árið 2006 (Skiba og Tobacman, 2006) og framboðið var orðið pað pað mikið árið 2007 að fleiri smálánafyrirtæki voru starfrækt í Bandaríkjunum heldur en McDonalds veitingastaðir (Stegman, 2007).

Pó svo að flestar rannsóknir á smálánum hafa verið gerðar í Bandríkjunum, eru til nokkrar rannsóknir sem hafa verið gerðar á Norðurlöndunum á pessu sviði en nýlega kom pó út rannsókn frá Finnlandi par sem farið var yfir neyslumynstur smálána hjá ungum Finnum og hvernig peir mátu sjálfa sig sem neytendur (Minna, Terhi-Anna, Risto og Jaana, 2009). Niðurstöðurnar bentu til pess að aldurshópurinn 18 til 29 ára, sem rannsakaður var, notaði lánin aðallega til að fjármagna skemmtanir og til kaupa á áfengi, tóbaki og mat. Í kjölfarið komu greiðslur/afborganir kreditkortaskulda, vaxtagjalda og samgöngukostnaður. Kyn hafði ekki áhrif á notkun smálána, en atvinna, tekjur, aldur og fjölskyldugerð hafði áhrif. Einstaklingar á aldrinum 18 til 23 ára voru líklegri til að nota lánin heldur en fólk á aldrinum 24 til 29 ára. Af peim sem sögðust hafa tekið smálán oftar en 6 sinnum voru 49\% með lægri atvinnutekjur af atvinnu en sem nam lágmarksframfærslu. Einnig kom fram að líklegra væri að einstaklingur tæki smálán ef hann var einstætt foreldri eða með lágar tekjur (Minna o.fl., 2009).

Ekki er hægt að heimfæra nema hluta pessara erlendu niðurstaðna yfir á íslenskan markað. Bandarísku lánin eru frábrugðin peim íslensku par sem leggja parf fram tryggingu í Bandaríkjunum í formi launaseðla og pví eiga einstaklingar án tekna erfiðara um vik að fá smálán (Stegman, 2007). Á Íslandi er pað ekki svo en neytendum er pó flett upp í vanskilaskrá Creditinfo áður en lán er veitt. Auk pess ríkir viss fákeppni á markaði á Íslandi og úr fáum kostum að velja. Рað er engin nýlunda að fólk á oft í erfiðleikum með að halda sig innan settra fjárhagslegra marka vegna útgjalda og á pað til að kaupa hluti sem ekki er til inneign fyrir (Laibson, 1997; Heidhues og Kőszegi, 2009). Nýleg finnsk rannsókn, sem fjallaði um smálananotkun ungs fólks, leiddi í ljós að peir sem notuðu smálán áttu erfitt með að ná stjórn á útgjöldum sínum, hélst illa á fé, taldi sig ekki vera skynsama neytendur og greiddu reikninga sína oft of seint (Minna o.fl., 2009). Hópurinn sem nýtti sér hvorki smálán né kreditkort kom mun betur út í samanburðinum. Í athugasemdakafla frumvarps sem lagt var fram 14. apríl 2011 um breytingar á lögum nr. 121/1994 um neytendalán (nú lög nr. 33/2013), kemur fram að vísbendingar séu um að neytendur sem hafa lélegt fjármálalæsi séu hlífðarlausir gagnvart markaðssókn smálánafyrirtækjanna og að pví purfi að bregðast við með lagasetningu. Pessar vísbendingar hafa hins vegar ekki verið kannaðar á vandaðan hátt hér á Íslandi.

Eitthvað hefur pó pokast í átt til betri varna fyrir neytendur smálána allra síðustu ár. Neytendastofa lagði árið 2015 dagsektir á 1909, Múla og Hraðpeninga, par sem pessi smálánafyrirtæki voru sökuð um að krefja neytendur um kostnað umfram lögbundið hámark (Viðskiptablaðið, 2015). Hraðpeningar og 1909 brugðust við pessu með pví að bjóða lántakendum sínum uppá að kaupa rafbók en pannig náðist inn kostnaður sem fyrirtækin töldu sig purfa vegna lánanna, en enn og aftur beitti Neytendastofa dagsektum (MBL, 2017). Einnig var fyrirtækið Aktíva sakað um blekkingar vegna vaxtakjara er pað bauð, en pegar allur kostnaður við lántökuna var skoðaður var dýrara að fá frá peim lán heldur en að nota hefðbundinn yfirdrátt (RÚV, 2016). 
Enn og aftur komust smálánafyrirtækin í fréttirnar pegar pau sendu óumbeðin smáskilaboð (SMS) til ungs fólks og buðu 20.000 kr lán, en með álögðum kostnaði hefðu vextir orðið vel yfir 3.000\% (Stundin, 2017). Jafnframt var talsverð umræða nýverið á RÚV pess efnis að ungt fólk leitar í sífellt meira mæli til umboðsmann skuldara vegna vangoldinna smálána og vítahrings lántöku hjá slíkum fyrirtækjum (RÚV, 2018). Rannsóknir og frekari skilingur á smálánum á Íslandi er pví orðinn löngu tímabær.

Tilgangur rannsóknarinnar var að kanna mun milli almennra neytenda og viðskiptavina smálánafyrirtækja á Íslandi. Í pessari grein er eftirfarandi rannsóknarspurning sett fram:

Er munur á fjármálalæsi viðskiptavina smálánafyrirtækjanna á Íslandi samanborið við hinn almenna neytenda á sama markaði?

Til að svara rannsóknarspurningunni verður farið yfir niðurstöður könnunnar sem send var til neytenda smálána og handahófskennds úrtaks íslenskra neytenda (almennra neytenda).

\section{Rannsóknaraðferð}

Í rannsókninni var stuðst við megindlega rannsóknaraðferð í formi spurningarkvarða til að bera saman tvo hópa, pað er neytendur smálána og almenna neytendur á Íslandi. Könnunin var hönnuð með hliðsjón af nokkrum erlendum fræðigreinum og rannsóknum (Minna o.fl., 2009; Puri, 1996) og spurningar fram- og bakpýddar yfir á íslensku.

\subsection{Pátttakendur og framkvæmd rannsóknar}

Tveir hópar voru fengnir til að svara spurningakönnuninni. Fyrri hópurinn samanstóð af neytendum smálánafyrirtækjanna Kredia ehf, Smálán ehf, Hraðpeningar ehf og 1909 ehf. Peir svöruðu 25 spurningakönnun rafrænt. Til að fá samanburð við hinn almenna íslenska neytenda var Félagsvísindastofnun Háskóla Íslands falið að senda spurningalista til 1.500 manns, handahófskennds úrtaks íslenskra neytenda.

Úrtakið samanstóð af tveim hópum. Önnur könnunin var send út á alla neytendur smálánafyrirtækjanna Kredia ehf, Smálán ehf, Hraðpeningar ehf og 1909 ehf og var hún send til neytenda fyrirtækjanna í rafrænu formi fréttabréfs. Sendur var beinn tengill á netkönnunina og var könnunin opinn á tímabilinu 8. nóvember til 12. desember 2012. Alls bárust 1.167 nothæf svör.

Leitað var til Félagsvísindastofnunar Háskóla Íslands um úrtak samanburðar hóps. Úrtakið samanstóð af fólki 18 ára og eldra af öllu landinu með slembiúrtaki úr pjóðskrá. Úrtakið var lagskipt eftir kyni, aldri og búsetu til pess að pað endurspeglaði sem best samsetningu kyns, aldurs og búsetu meðal landsmanna. Рað endurspeglar pví eins vel og mögulegt er hinum "almenna" neytenda á Íslandi. Alls voru 1.465 manns sem fengu sendan hlekk á könnunina af peim fylltu 840 manns út könnunina og var svarhlutfall pví $57 \%$.

\subsection{Mælitæki}

Upphaflega var saminn 30 spurningalisti sem var forprófaður á premur einstaklingum, leiðréttur og bættur út frá tillögum peirra. Að pví loknu var listinn lagður fyrir 118 nemendur Fjölbrautarskólans í Breiðholti og áreiðanleiki listans kannaður. Að öllum lagfæringum loknum var ákveðið að nota 25 spurningar.

Ákveðinn munur var á peim tveim listum sem að lokum voru sendir út til pátttakenda pessara rannsóknar, en spurningarnar sem notaðar voru til að byggja niðurstöður á voru pær sömu milli hópa. Munurinn fólst tveimur aukaspurningum til neytenda smálána og fjölda bakgrunnsbreyta. Listinn sem fór til neytenda smálánafyrirtækjanna innihélt pví 25 spurningar eins og áður var talið. Notaður var hvati í formi priggja gjafabréfa í verslunar- 
miðstöðina Kringluna. Listinn sem sendur var á úrtak Félagsvísindastofnunar samanstóð af 31 spurningu og innihélt ekki hvata.

Spurningar 1 - 4 voru byggðar á finnskri rannsókn frá árinu 2009 um notkun ungra Finna á smálánum (Minna o.fl., 2009). Ekki voru unnar niðurstöður upp úr pessum spurningum við vinnslu greinarinnar.

Spurning 5 mældi hvatvísi svarenda ogvar fengin úr bókinni „Handbook of Marketing Scales", en skalinn sjálfur er frá árinu 1996 eftir Radhika Puri. Ekki voru unnar niðurstöður upp úr pessum spurningum við vinnslu greinarinnar.

Fjármálalæsi var mælt í spurningum 6-18. Tvær víddir fjármálalæsis voru athugaðar; annars vegar kunnátta og hins vegar viðhorf svarenda til fjármálalæsis. Stuðst var við lista Atkinson og Messy (2012) úr OECD rannsókn peirra á fjármálalæsi. Pýðingarnar á spurningarlista peirra voru fengnar úr rannsóknum Breka Karlssonar. Atkinson og Messy innihélt fleiri spurningar og einnig mældu peir enn aðra vídd fjármálalæsis, hegðun. Sú vídd var ekki mæld á sama hátt í pessari rannsókn, en eins og áđur kom fram var fjármálahvatvísi frekar mæld. Aðrar spurningar voru bakgrunnsspurningar meðal annars um kyn, aldur og tekjur.

Einkun í fjármálalæsi var reiknuð út fyrir hvern svarenda sem leiddi í ljós færni hans. Hæst var hægt að fá 7 stig fyrir kunnáttuhlutann og 4 stig fyrir viðhorfshlutann.

Í könnuninni sem send var til neytenda smálána voru lagðar fyrir spurningar sem snéru að neyslu á smálánum. Spurt var um til hvers smálánin voru notuð og hvort neytendur hefðu nýtt sér pau til að greiða upp fyrri smálán. Spurningarnar voru byggðar á spurningum 1-4 úr rannsókn Minna o.fl. (2009).

\section{Niðurstöður}

Alls bárust 2007 nothæf svör við spurningarlistnum tveimur; 1.167 frá viðskiptavinum smálánafyrirtækjanna og 840 úr könnun Félagsvísindastofnunar. Meginmarkmið rannsóknarinnar var að greina hvort finna mætti marktækan mun á fjármálalæsi viðskiptavina smálánafyrirtækjana og hins almenna neytenda. Til að úrtak smálánapega væri sambærilegt við úrtak Félagsvísindastofnunar var pað vegið með tilliti til kyns og aldurs í tölfræðiprófum.

Almennir neytendur $(M=5,07 ; S F=1,77)$ mældust með marktækt $(t(1413)=6,337, p$ $<0,05)$ meiri pekkingu á sviði fjármála en viðskiptavinir smálánafyrirtækjanna $(M=4,47$; $S F=1,72$ ). Mynd 1 sýnir einnig að almennum neytendum gekk betur á kunnáttuhluta könnuninnar. Pannig svöruðu 25,3\% öllum spurningum rétt, en einungis 9,8\% viðskiptavina smálánafyrirtækjanna voru með öll svör rétt.

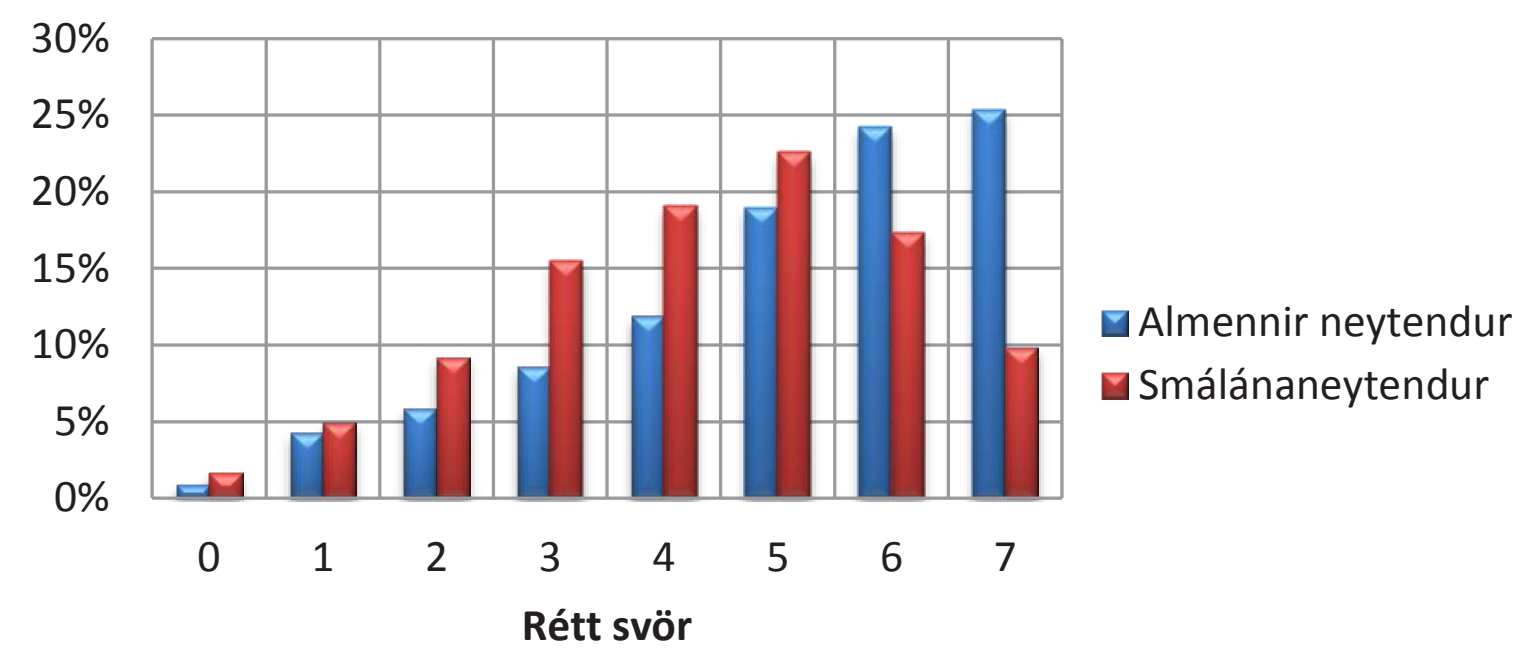

Mynd 1. Dreifing réttra svara í kunnáttuhluta fjármálalæsis 
Pegar viðhorfshluti fjármálalæsis var skoðaður kom í ljós að marktækur munur $(t(1360)=$ $5,935, p<0,05)$ var á milli almennings $(M=3,70 ; S F=, 75)$ og neytenda smálána $(M=3,46$; $S F=, 76)$ og gefur sú niðurstaða pví einnig til kynna verri stöðu neytenda smálána. Petta gefur til kynna að peir geri síður fjármálaáætlanir, leggi fyrir og taki meiri fjárhagslega áhættu. Á mynd 2 má sjá viðhorf svarenda beggja hópa til fjármála.

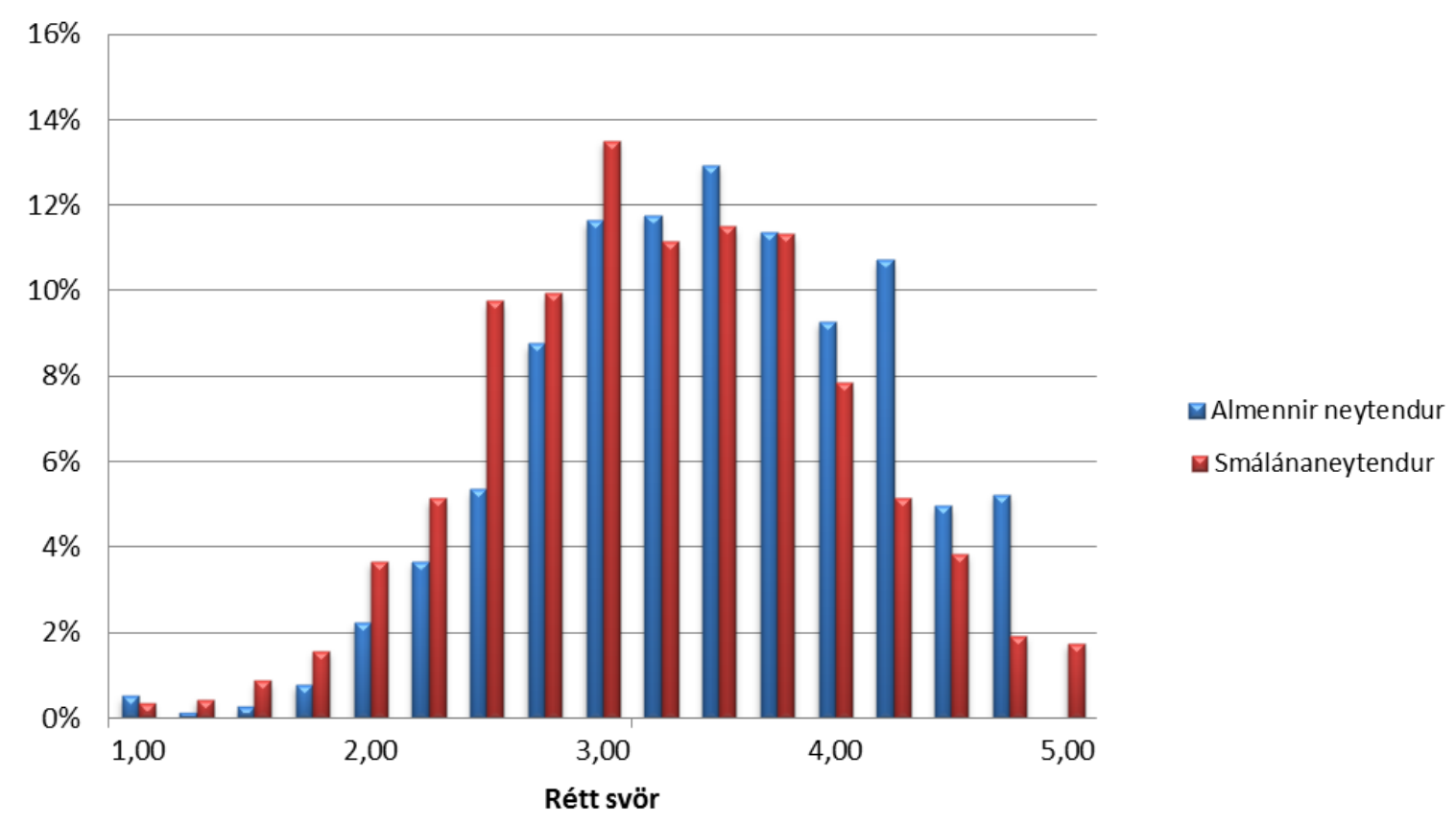

Mynd 2. Dreifing réttra svara í viðhorfshluta fjármálalæsis

Pegar samsett einkunn úr kunnáttu og viðhorfshluta fjármálalæsis er skoðuð mælist einnig mærktækur $(t(1360)=10,689, p<0,05)$ munur á milli almennings $(M=8,99 ; S F=1,78)$ og neytenda smálána $(M=7,93 ; S F=1,86)$. Mynd 3 sýnir samsetta einkunn svarenda við öllum spurningum varðandi fjármálalæsi.

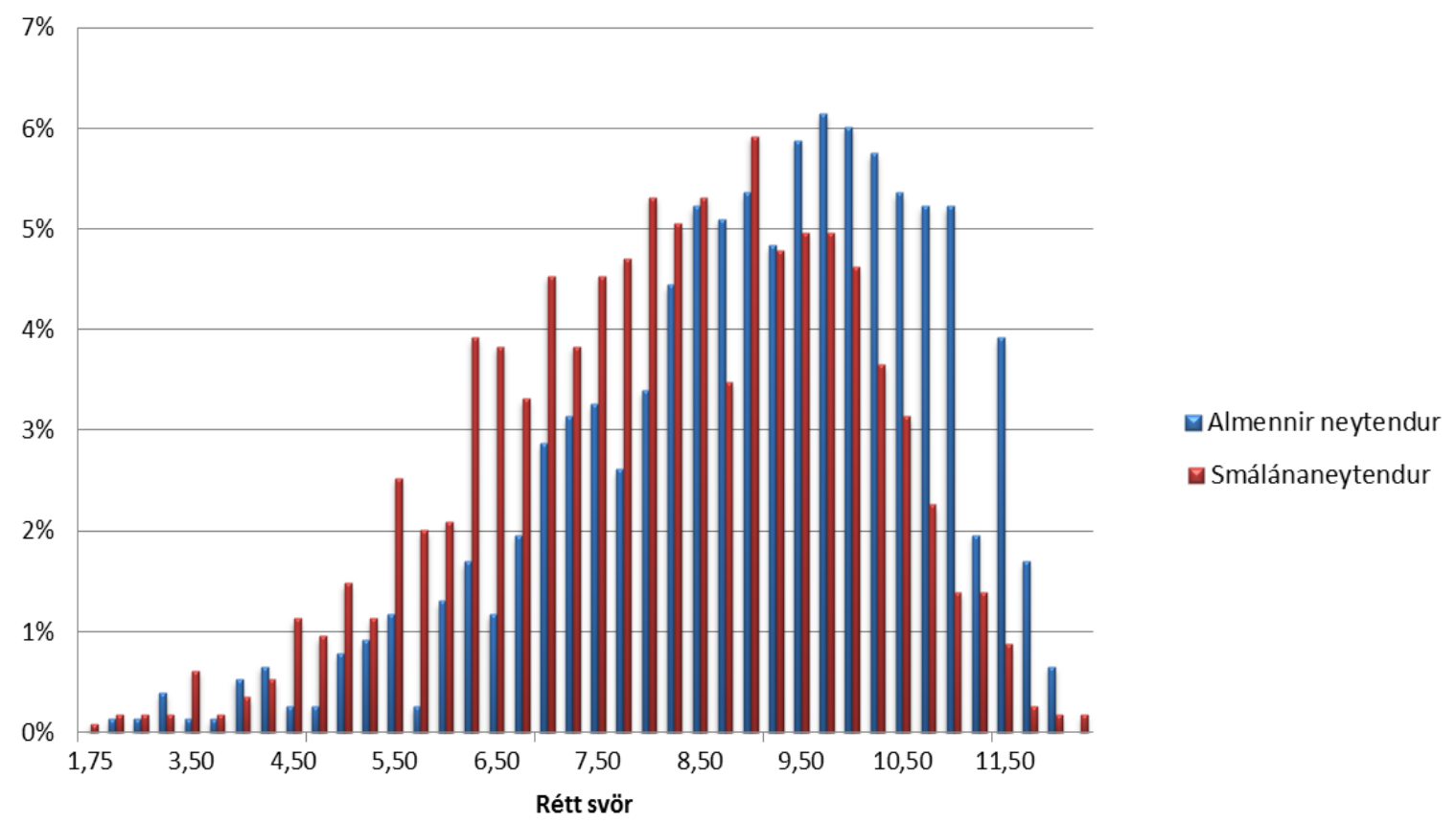

Mynd 3. Dreifing réttra svara í fjármálalæsi 
Í ljósi pessara niðurstaðna er óhætt að svara rannsóknarspurningunni sem lagt var upp með játandi, p.e. almennir neytendur eru betur læsir á fjármál heldur en viðskiptavinir smálánafyrirtækjanna á Íslandi.

Sé munurinn milli neytenda smálána og almennra neytenda á Íslandi skoðaður sérstaklega má sjá að pessir hópar eru að morgu leyti frábrugðnir hvor öðrum. Í töflum 1 og 2 má sjá helstu bakgrunnsupplýsingar beggja hópanna.

Tafla 1. Bakgrunnsupplýsingar almennra neytenda

\begin{tabular}{lllr}
\hline Kyn pátttakenda & \multicolumn{3}{c}{ Mánaðarlegar ráðstöfunartekjur pátttakenda } \\
\hline Karlar & $49,2 \%$ & $0-100.000 \mathrm{kr}$. & $6,0 \%$ \\
Konur & $50,8 \%$ & $100.001-200.000 \mathrm{kr}$. & $21,4 \%$ \\
& & $200.001-300.000 \mathrm{kr}$. & $32,5 \%$ \\
Aldur pátttakenda & $300.001-400.000 \mathrm{kr}$. & $18,1 \%$ \\
$18-20$ ára & $1,3 \%$ & $400.001-500.000 \mathrm{kr}$. & $12,1 \%$ \\
$21-22$ ára & $2,1 \%$ & 500.001 kr. eða hærra. & $9,9 \%$ \\
$23-25$ ára & $3,1 \%$ & Hæsta prófgráða pátttakenda & $33,5 \%$ \\
$26-35$ ára & $16,4 \%$ & Stúdentspróf eða lægra & $21,6 \%$ \\
36-50 ára & $29,9 \%$ & Tækniskólapróf (annað en BS-eða BA próf) & $30,8 \%$ \\
& $47,2 \%$ & Grunnpróf úr háskóla (BA/BS) & $14,1 \%$ \\
\hline
\end{tabular}

Tafla 2. Bakgrunnsupplýsingar neytenda smálána

\begin{tabular}{lllr}
\hline Kyn pátttakenda & & Mánaðarlegar ráðstöfunartekjur pátttakenda \\
\hline Karlar & $43,8 \%$ & $0-100.000 \mathrm{kr}$. & $12,5 \%$ \\
Konur & $56,2 \%$ & $100.001-200.000 \mathrm{kr}$. & $37,2 \%$ \\
& & $200.001-300.000 \mathrm{kr}$. & $29,1 \%$ \\
Aldur pátttakenda & $300.001-400.000 \mathrm{kr}$. & $12,3 \%$ \\
18 -20 ára & $7,8 \%$ & $400.001-500.000 \mathrm{kr}$. & $3,9 \%$ \\
$21-22$ ára & $20,6 \%$ & 500.001 kr. eða meira. \\
$23-25$ ára & $33,4 \%$ & Hæsta prófgráða pátttakenda & $71,2 \%$ \\
$26-35$ ára & $27,1 \%$ & Stúdentspróf eða lægra & $7,5 \%$ \\
$36-50$ ára & $11,0 \%$ & Tækniskólapróf (annað en BS-próf) & $16,4 \%$ \\
51 ára eða eldri & $0,0 \%$ & Grunnpróf úr háskóla & $5,0 \%$ \\
\hline
\end{tabular}

Strax má sjá að pó nokkur munur er á hópunum. Myndir 4, 5 og 6 sýna muninn á aldri, tekjum og menntun hópanna. 


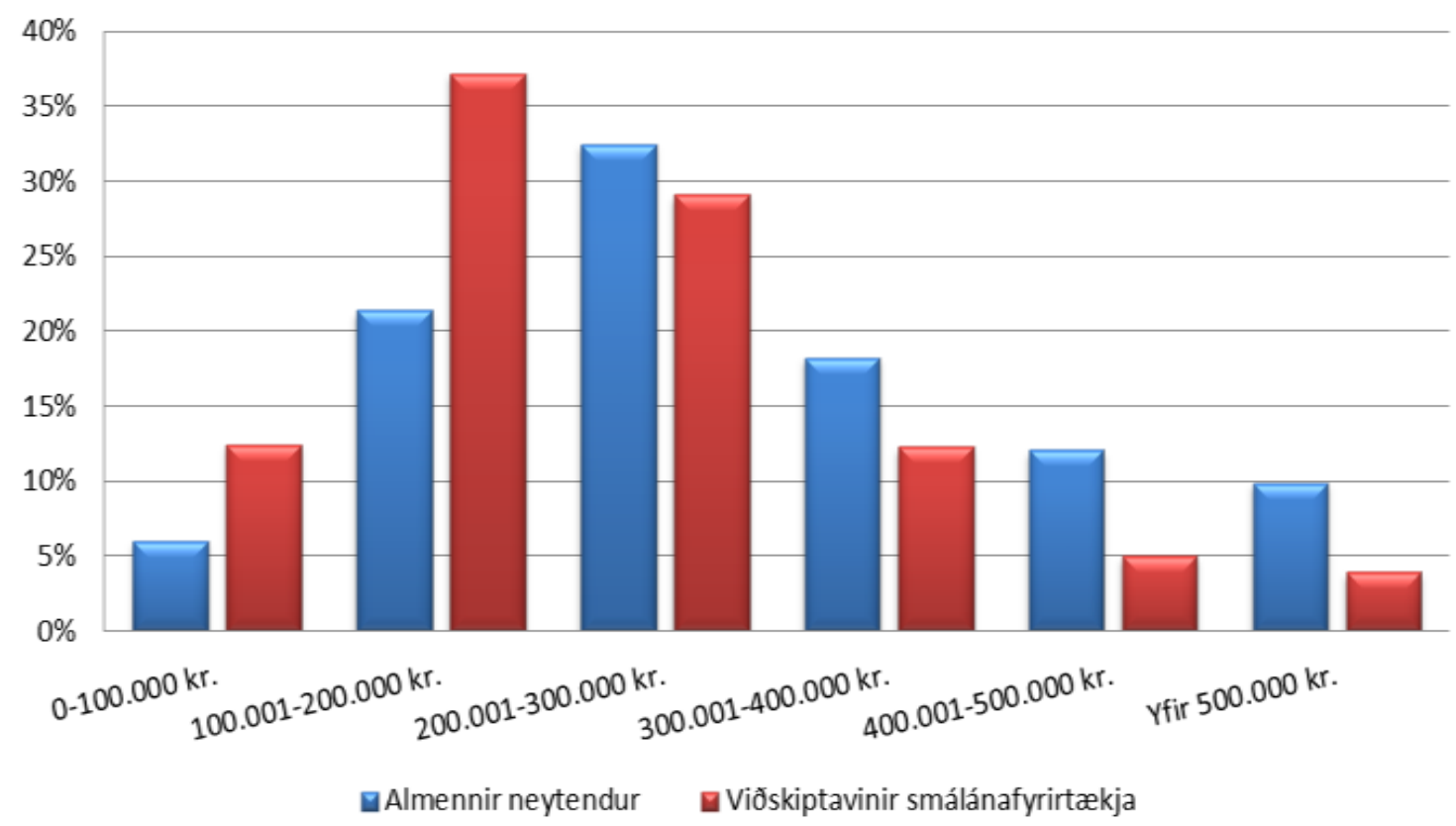

Mynd 4. Mánaðarlegar ráđstöfunartekjur hópanna

Neytendur smálána hafa ívið lægri ráðstöfunartekjur, 49,7\% með 200.000 kr. eða minna á mánuði samanborið við 27,4\% hjá almennum neytendum. Eins og sést á mynd 5 eru viðskiptavinir smálánafyrirtækjanna einnig mun yngri en hin almenni neytandi en sú ákvörðun að safna svörum frá Félagsvísindastofnun gæti skýrt hluta pess munar.

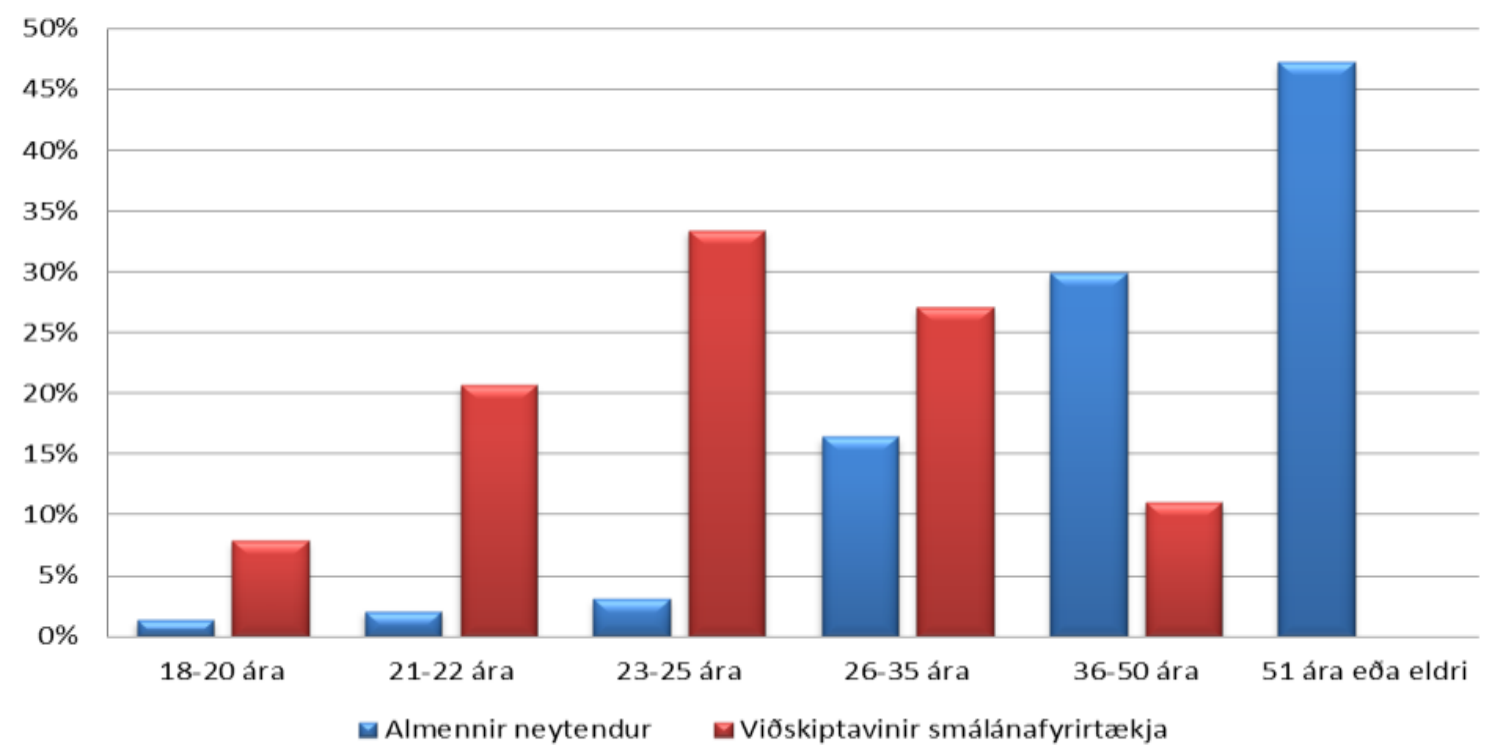

Mynd 5. Aldursdreifing hópanna

\section{Umræða}

Út frá hagfræðilegu sjónarmiði ætti fólk ávalt að velja ódýrustu fjármögnunarleiðina. Sú er pó ekki alltaf raunin vegna ýmissa annara pátta sem geta haft áhrif á val neytenda. Mannlegir pættir, sem áhrif geta haft á val neytenda eru til dæmist fyrri reynsla, ávöxtunarkrafa og smekkur. Staðsetning neytenda getur einnig takmarkað möguleika peirra til fjármögn- 
unar sem og áhrif fyrri ákvarðna, til að mynda vanskil eða gjaldprot (Huston, 2010). Pví parf pekking á fjármögnunarkostum, fjármálalæsi og vitneskja um lántökukostnað ekki að vera megináhrifapátturinn pegar kemur að vali neytenda (Huston, 2012).

Hóparnir sem bornir voru saman í pessari rannsókn voru pó nokkuð frábrugðnir hvor öðrum. Viðskiptavinir smálánafyrirtækjanna voru yngri og t.a.m. var 61,8\% á aldrinum 18-25 ára en aðeins 6,5\% almennra neytenda. Viðskiptavinir smálánafyrirtækjanna höfðu einnig lægri tekjur, 49,7\% undir 200 púsund krónum í ráðstöfunartekjur mánaðarlega samanborið við 27,4\% almennra neytenda. Einnig höfðu almennir neytendur oftar lokið fyrstu háskólagráðu, p.e. 30,9\% en aðeins 16,4\% viðskiptavina smálánafyrirtækjanna höfðu lokið sams konar gráðu. Áhugavert væri pví að skoða muninn á milli pessara hópa nánar. Til dæmis eru persónuleikabreytur eins og hvatvísi í fjármálum möguleg skýring á neyslu smálána.

Mikill skortur er á fræðilegri umfjöllun hérlendis um pennan málaflokk en erlendis hafa ýmis álitamál verið til umræðu honum tengdum. Til að mynda voru áhrif algers banns við smálánastarfsemi tveggja fylkja í Bandaríkjunum metin og komust fræðimenn að peirri niðurstöðu að betra hefði verið að ganga ekki svo langt. Kostnaður við lánin hefur einnig verið kannaður og bentu niðurstöður til pess að аð miðað við tegund, upphæð, lánstíma, afskriftir og rekstarkostnað væri kostnaðurinn skiljanlegur.

Aðkallandi er að kanna hvers vegna neytendur taka lánin og hvort pessi lán séu peim til trafala. Fræðilegar rannsóknir á pessu sviði skortir ennpá og fyrir vikið umræðan tengd smálánum ekki verið byggð á mikilli pekkingu um áhrif peirra á samfélagið.

Par sem stærsti hluti rannsókna á pessu sviði hafa sýnt fram á jákvæð tengsl milli fjármálalæsis og fjárhagslegrar velgengni má einnig leiða að pví líkur að átak til að auka fjármálalæsi sé pjóðhagslega hagkvæmt. Neytendur með meira fjármálalæsi skilja betur kosti sem peim bjóðast og átta sig einnig betur á raunverulegu virði peninga og hvernig hagkvæmast er að nota pá.

Gagnasöfnunin sem ráđist var í við vinnslu greinarinnar gefur svigrúm til frekari úrvinnslu gagna til frekari rannsókna og umræðu um málefni neytenda. Hér var pví aðeins svarað hvort munur væri á fjármálalæsi viðskiptavina smálánafyrirtækja annars vegar og almennra neytenda hins vegar. Раð er von höfunda að í kjölfar pessarar greinar verið fleiri kannanir gerðar á pessum markaði til að varpa skýrara ljósi á neytendur og neyslu fjármálaafurða. Рað væri t.a.m. áhugavert að gera rannsókn á pví hvort fjármálalæsi muni aukast pegar pað verður orðið hluti af PISA könnuninni, en tíminn einn mun leiða pað í ljós.

\section{Heimildir}

Atkinson, A., Mckey, S., Collard, S. og Kempson, E. (2007). Levels of Financial Capability in the UK. Public Money og Management, 27(1), 29-36.

Atkinson, A. og Messy, F. (2012). Measuring Financial Literacy: Results of the OECD. International Network on Financial Education (INFE) Pilot Study. (Vinnuskýrsla OECD nr. 15). París: OECD. Sótt 26. mars 2018 af http://dx.doi.org/10.1787/5k9csfs90fr4-en

Bakken, M. R. (1967). Money management understandings of tenth grade students. National Business Education Quarterly, 36, 6.

Braunstein, S. og Welch, C. (2002). Financial literacy: An overview of practice, research, and policy. Federal Reserve Bulletin , 88(11), 445-457.

Breki Karlsson. (2010). Ferð til fjár - Leiðarvísir um fjármál fyrir ungt fólk. Reykjavík: Oddi.

Breki Karlsson og Bryndís B. Ásgeirsdóttir. (2009). Rannsókn á fjármálalæsi á Íslandi. Reykjavík: Stofnun um fjármálalæsi og rannsóknir og greining.

David, M. (2004). The UK Mortage Market: Taking a Larger-Term View. Norwich. UK: HMSO, Licensing Division. Sótt 26. mars 2018 af http://news.bbc.co.uk/nol/shared/bsp/hi/pdfs/12_03_04_miles.pdf

Garg, N. og Singh, S. (2018). Financial literacy among youth. International Journal of Social Economics, 45(1), 173-186.

Gathergood, J. (2011). Self-control, financial literacy and consumer over-indebtedness. Journal of Economic Psychology, 33, 590-602. 
Heidhues, P. og Kőszegi, B. (2009). Futile attempts at self-control. Journal of the European Economic Association, $7(2-3), 423-434$.

Hraðpeningar.ehf. (2018). Smálán, Hraðpeningar.ehf. Sótt 9 mars 2018 frá https://hradpeningar.de

Huston, S. J. (2010). Measuring financial literacy. The Journal of Consumer Affairs, 44(2), 296-316.

Huston, S. J. (2012). Financial literacy and the cost of borrowing. International Journal of Consumer Studies, 36, 566-572.

Jumpstart Coalition for Personal Financial Literacy. (2005, júní). 2004 personal financial survey of high school seniors. Sótt 26. mars 2018 af http://www.jumpstart.org/survey.html

Lawrence, E. og Elliehausen, G. (2008). A comparative analysis of payday loan customers. Contemporary Economic Policy; Huntington Beach, 26(2), 299-316.

Laibson, D. (1997). Golden eggs and hyperbolic discounting. Quarterly Journal of Economics, 112, $443-477$.

Lusardi, A. og Mitchell, O. (2006). Financial Literacy and Planning: Implications for Retirement Wellbeing. Pension Research Council Working Paper No. 1. Sótt 26. Mars 2018 af https://deepblue.lib.umich.edu/bitstream/ handle/2027.42/49432/wp108.pdf?sequence=1

Lusardi, A. og Mitchell, O. (2007). Baby boomer retirement security, the role of planning, financial literacy and housing wealth. Journal of Monetary Economics, 54, 205-224.

Lusardi, A. og Tufano, P. (2009). Debt literacy, Financial experience and overindebtedness. (Vinnuskýrsla NBER nr. 14808). Cambridge: NBER. Sótt 26. mars 2018 af http://www.nber.org/papers/w14808

Mandell, L. (1997). Our Vulnerable Youth: The Financial Literacy of American 12th Graders. Washington, DC: The Jump\$tart Coalition for Personal Financial Literacy.

Mandell, L. (2008). Financial Literacy of High School Students, in Overcoming the Saving Slump: How to Increase the Effectiveness of Financial Education and Saving Programs. Chicago: University of Chicago Press.

Minna, A., Terhi-Anna, W., Risto, K. og Jaana, L. (2009). The use of small instant loans among young adults - a gateway to a consumer insolvency? International Journal of Consumer Studies, 33(4), 407-415.

Morgunblaðið. (5. september 2009). Kynlíf frekar rætt en fjármál. Sótt 26. mars 2018 frá http://www.mbl.is/ greinasafn/grein/1298883/

Morgunblaðið. (29. október 2009). Bjóða smálán með 608\% ársvöxtum. Sótt 26. mars 2018 frá http://www.mbl. is/vidskipti/frettir/2009/10/29/bjoda_smalan_med_608_prosent_arsvoxtum/

Morgunblaðið. (20. október 2012). Smálán takmörkuð við 80.000 kr. Sótt 26. mars 2018 frá http://www.mbl.is/ frettir/innlent/2012/10/22/smalan_takmorkud_vid_80_000_kr/

OECD. (2005). Improving financial literacy: analysis of issues and policies. Sótt 26. mars 2018 af http:// www.keepeek.com/Digital-Asset-Management/oecd/finance-and-investment/improving-financial-literacy_9789264012578-en

OECD. (2015). PISA. 2015. Bls 13. Sótt 16 júní 2018 af https://www.oecd.org/pisa/pisaproducts/46962580.pdf

Parhaat Pikavipit. (7. apríl. 2012). Netin parhaat pikavipit - pikavippi [Myndband]. Sótt 26. mars 2018 af http:// www.youtube.com/watch?v=dji0235s_xA

PIPARTBWA. (23. mars. 2012). Smálán - Ekkert stórmál [Myndband]. Sótt 26. mars af http://www.youtube. $\mathrm{com} /$ watch?v=t0LzNiPA964

Puri, R. (1996). Measuring and Modifying Consumer Impulsiveness: A Cost - Benefit Accessibility Framework. Journal of Consumer Psychology, 5(2), 87-113.

Ríkisútvarpið. (18. september 2012). Smálánafyrirtæki. Sótt 26. mars 2018 frá http://www.ruv.is/ruv/smalanafyrirtaeki

Ríkisútvarpið. (17 júlí 2016). Aktívalán tvisvar sinnum dýrari en yfirdráttur, Sótt 23. mars 2018 af http://www. ruv.is/frett/aktivalan-tvisvar-sinnum-dyrari-en-yfirdrattur

Ríkisútvarpið. (13 febrúar 2018). Smálán að sliga ungt fólk. Sótt 26.mars af http://www.ruv.is/frett/smalan-adsliga-ungt-folk

Skiba, P. og Tobacman, J. (2006). Payday Loans, Uncertainty, and Discounting: Explaining Patterns of Borrowing, Repayment, and Default. Sótt 26. mars 2018 af http://citeseerx.ist.psu.edu/viewdoc/download?doi=10.1.1.208.9025\&rep=rep1\&type $=$ pdf

Strotz, R. H. (1956). Myopia and inconsistency in dynamic utility maximization. Review of Economic Studies, 23, 165-180.

Stegman, M. A. (2007). Payday Lending. Journal of Economic Perspectives, 21(1), 169 -190.

Stundin. (23. maí 2017). Smálána fyrirtæk hvetja fólk til að taka kostnaðarsöm lán í smáskilaboðum, sótt á vef Stundarinnar 1. mars 2018 https://stundin.is/frett/smalanafyrirtaeki-bjoda-folki-kostnadarsom-lan-i-smaskilabodum/

van Rooij, M. C., Lusardi, A. og Alessie, R. J. (2011a). Financial literacy and retirement planning in the Netherlands. Journal of Economic Psychology, 32, 593-608.

van Rooij, M. C., Lusardi, A. og Alessie, R. J. (2011b). Financial literacy and stock market participation. Journal of Financial Economics, 101, 449-472.

Viðskiptaráðuneytið. (2009). Fjármálalæsi á Íslandi - skýrsla nefndar á vegum viðskiptaráðherra. Reykjavík.

Viðskiptablaðið. (20. nóvember 2015). 1909, Múla og Hraðpeningar purfa að greiða dagsektir. Sótt 17. mars 2018 af http://www.vb.is/frettir/1909-mula-og-hradpeningar-thurfa-ad-greida-dagsektir/122734/?q=Sm\%C3\%A11\%C3\%A1nafyrirt\%C3\%A6ki

Worthhington, A. C. (2006). Predicting financial literacy in Australia. Financial Service Review, 15(1), 59-79. 